\title{
18q-症候群に対する大動脈弁置換術の一例
}

\author{
早津 幸弘 ${ }^{1)}$, 安達 理 ${ }^{1)}$, 長沼 政亮 $^{1)}$, 増田 信也 ${ }^{1)}$, \\ 秋山 正年 ${ }^{1)}$, 木村 正人 ${ }^{2)}$, 齋木 佳克 ${ }^{1)}$ \\ ${ }^{1)}$ 東北大学大学院医学系研究科外科病態学講座心臟血管外科学分野 \\ ${ }^{2)}$ 東北大学大学院医学系研究科発生・発達医学講座小児病態学分野
}

\section{Aortic Valve Replacement for a Patient with 18q Syndrome}

\author{
Yukihiro Hayatsu' ${ }^{1}$, Osamu Adachi ${ }^{1)}$, Masaaki Naganuma ${ }^{1)}$, Shinya Masuda ${ }^{1)}$, \\ Masatoshi Akiyama ${ }^{1)}$, Masato Kimura ${ }^{2)}$, and Yoshikatsu Saiki ${ }^{1)}$ \\ ${ }^{1)}$ Division of Cardiovascular Surgery, Tohoku University Graduate School of Medicine, Miyagi, Japan \\ ${ }^{2)}$ Department of Pediatrics, Tohoku University Graduate School of Medicine, Miyagi, Japan
}

\begin{abstract}
A 19-year-old male presented with a history of mild muscle weakness, hypoacusis, cleft lip plate, and delayed development since birth. However, a chromosomal analysis had been refrained. At the age of 16 years, a heart murmur was identified for the first time during a school checkup, and aortic valve regurgitation was identified by echocardiography. At that time, he was diagnosed with partial trisomy and monosomy 18 based on G-banding analysis and was then referred to our hospital for comprehensive management of the chromosomal disease and aortic valve insufficiency. The regurgitation gradually progressed, and we performed aortic valve replacement with a mechanical valve. The postoperative course was uneventful, and pathological examination revealed that each leaflet of the aortic valve was thickened and hyalinized mainly around the Arantius body. Alcian blue and periodic acid-Schiff staining also confirmed the myxomatous change around the aortic valve and wall. Hematoxylin-eosin staining confirmed the lengthening, disruption, and effacement of the collagen fiber in aortic media. However, we found no significant macroscopic findings on the aortic wall. Single nucleotide polymorphism and comparative genomic hybridization microarray analysis revealed a deletion only at the long arm of chromosome 18, and the patient was diagnosed with 18q-syndrome. We report the first case of partial monosomy 18 during adolescence requiring cardiovascular surgery and discuss the cardiovascular features of this chromosomal abnormality.
\end{abstract}

Keywords: chromosomal abnormality, 18q-syndrome, aortic-valve replacement

症例は 19 歳男性で, 出生時より筋力の軽度低下, 難聴, 口唇口蓋裂, 軽度発達遅延等を認めていたが, 染色体検査は行っていなかった１6歳時に心雑音を指摘され，大動脈弁閉鎖不全症の診断となり，そ の際に行われた染色体検査（G-band 解析）にて，18 番染色体部分トリソミーおよび部分モハソミーの 診断 [46, XY, add（18）（q21.2）］となった. 包括的な医療を希望し当院へ紹介となり，大動脈弁閉鎖 不全症に対し大動脈弁置換術（機械弁）を行った. 病理所見では, 大動脈弁は 3 尖とも線維性に肥厚 しており，弁尖が結節状に変化していた。また，Alcian-blue 陽性の粘液状基質の沈着が目立ち，中等 度の変性を伴う大動脈弁の組織像であった．大動脈壁も同様に中等度以上の変性を伴う大動脈壁の組 織像であった. 外来経過中に行ったアレイ CGH+SNP 解析では, 18 番染色体長腕にコピー数の変化 を認め, 最終的には 18 番染色体長腕部分モハソミー（18q-症候群）の診断となった. 青年期に達し心 臓手術が施行された 18 部分モノソミーの報告はなく，若干の考察を加え報告する.

2018 年 12 月 19 日受付, 2019 年 3 月 5 日受理

著者連絡先：=980-8574 宮城県仙台市青葉区星陵町 1-1 東北大学大学院医学系研究科外科病態学講座心臓血管外科学分野 齋木佳克 doi: $10.9794 /$ jspccs.35.179 


\section{症例}

症例：19歳男性

主訴：易疲労感

既往歴：口唇口蓋裂（形成術施行）, 先天性両側外耳 道閉鎖による聴覚障害（外耳道・鼓膜および耳小骨形 成術施行), 左側関節滑膜包炎

生活歴：中学校までは公立中学校へ進学していた。中 学校で, 勉強がやや難しく感じ，さらに難聴があった ためコミュニケーションをとるのが難しいことがあっ た. 最近では, IQ は 80 程度から 60 程度へ低下して いた。

現病歴：在胎 41 週 4 日. 出生時体重 3,170g. 出生時 より, 筋力の軽度低下, 難聴, 口唇口蓋裂, 軽度発達 遅延等を認めていたが，染色体検査は行われていな かった. 16 歳時の学校検診で心雑音を指摘され，精 査の結果，大動脈弁閉鎖不全症の診断となった。 そ の際に行われた染色体検査（G-band 解析）にて，18 番染色体長腕 q 21.2 が欠失し，その断端に由来不明
な断端の付加を認めたため, 18 番染色体部分トリソ ミーおよび部分モノソミーの診断 [46, XY, add (18) （q21.2）となった（Fig. 1)。これらは，両親のいず れかの均衡型相互転座から由来している可能性が考 えられたが，両親の染色体検査を行えなかったため， 詳細は不明であった。その後経過観察となったが, 18 歳時のカテーテル検査で大動脈閉鎖不全症の増悪 （Sellers III 度）を認め，手術適応と判断された。染色 体異常も含めた包括的医療を求め, 当院紹介となっ た。

理学・検査所見：身長 $161 \mathrm{~cm}$, 体重 $47 \mathrm{~kg}$. 聴診 上, Erbの領域を最強点とする拡張期雑音 (Levine IV/VI）を聴取した。また，本症例では上記既往歴に 加え, 精神発達遅滞, 漏斗胸, 内反足, 軽度側弯症, 軽度手指屈曲異常を認め, さらに父親からの病歴聴取 では，幼少期に停留精巣（現在は改善）を認めてい た．顔貌は，口蓋裂に伴う軽度変形のみで，三日月様 顔貌や顔面中部低形成などは認めなかった。

血液検査：白血球 $8700 / \mu \mathrm{L}$ ，赤血球 $5.1 \times 10^{6} / \mu \mathrm{L} ， へ$

(A)

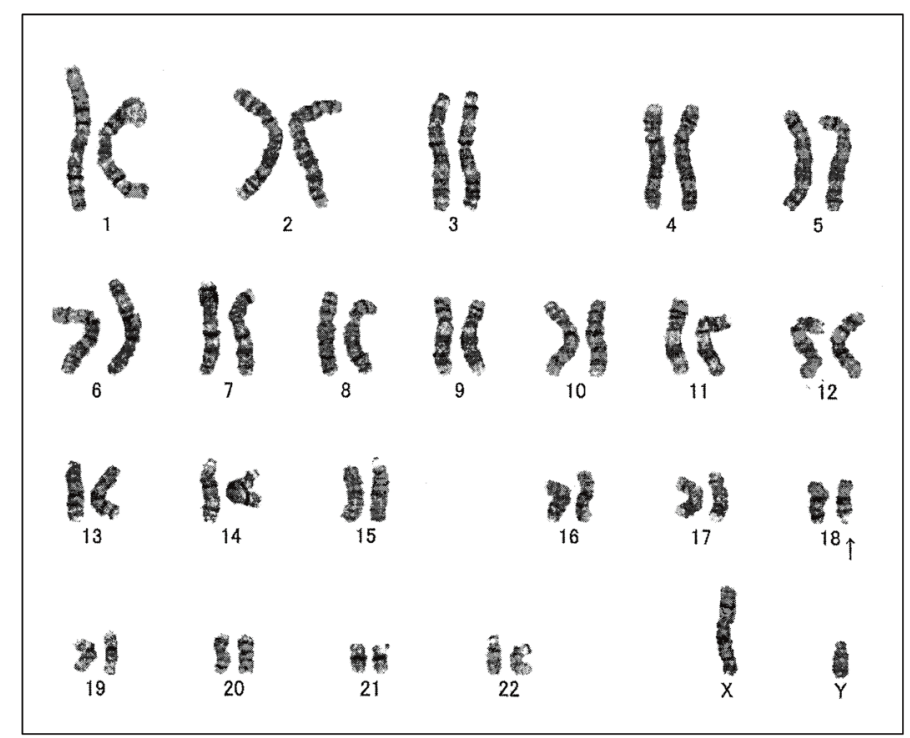

(B)

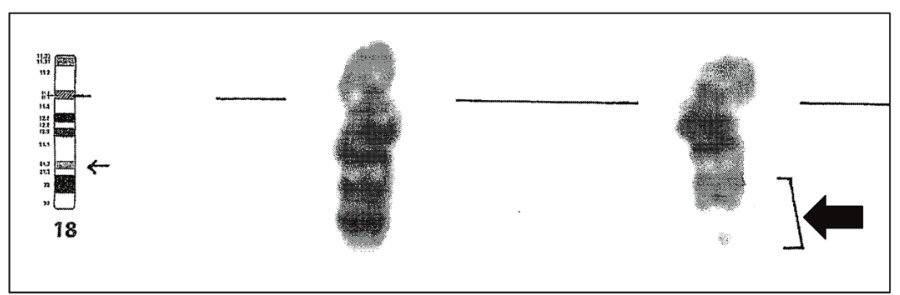

Fig. 1 Chromosomal testing (G-banding analysis)

(A) The deletion on the long arm of chromosome 18 was confirmed (narrow arrow). (B) The deletion located on q21.2 in chromosome 18, and the fragment of unknown origin was attached to the broken end of chromosome 18 (bold arrow). 
モグロビン $15.0 \mathrm{~g} / \mathrm{dL}$, 血小板 $14.8 \times 10^{4} / \mu \mathrm{L}$, 総ビリ ルビン $0.5 \mathrm{mg} / \mathrm{dL}, \mathrm{ALP} 229 \mathrm{U} / \mathrm{L}, \gamma \mathrm{GTP} 17 \mathrm{U} / \mathrm{L}$, AST 13U/L, ALT 10U/L, LDH 162U/L, ChE 264U/L, BUN $12 \mathrm{mg} / \mathrm{dL}$, Cr $0.82 \mathrm{mg} / \mathrm{dL}, \mathrm{TP} 6.4 \mathrm{~g} / \mathrm{dL}$, 電解質異常な し, 凝固系の異常なし, BNP $12.5 \mathrm{pg} / \mathrm{mL}$

胸部レントゲン：心胸郭比 $40.3 \%$. 肺うつ血は認め ない.

心電図：洞調律で脈拍 63 回/分. 軸偏位なし.

呼吸機能：軽度拘束性障害［肺活量 3.11L（75.7\%)， 一秒量 $2.89 \mathrm{~L}(93.0 \%)]$

心エコー：左室拡張末期径/収縮末期径 $=57 / 38 \mathrm{~mm}$, 左室駆出率 $60 \%$, 大動脈弁中央から中程度～重度の 大動脈弁逆流を認めた. 大動脈弁は 3 尖であり, 各弁 尖の肥厚が著明であった。大動脈弁輪径は $21 \mathrm{~mm}$, バルサルバ洞 $28 \mathrm{~mm}$, sinotubular junction（STJ） $20 \mathrm{~mm}$. また, 軽度の左室緻密化障害が疑われた
(Fig. 2).

心臓カテーテル検査：大 動 脈 圧 118/61（平 均 88） $\mathrm{mmHg}$, 肺動脈楔入圧 $7 \mathrm{mmHg}$, 右室圧 $15 / 2 \mathrm{mmHg}$, 右房圧 $2 \mathrm{mmHg}$, 心拍出量（心係数） $4.7 \mathrm{~L} / \mathrm{min}\left(3.1 \mathrm{~L} / \mathrm{min} / \mathrm{m}^{2}\right)$, 左室駆出率 $56.8 \%$, 大動 脈造影にて Sellers III 度の大動脈弁逆流を認めた。

術中所見および経過：人工心肺を用いた体外循環下 に心停止とし，大動脈弁を観察すると，各弁尖は全 体的に浮腫状の肥厚を呈し, 一部には硬化性変化も 認めた. また, 各弁尖は Arantius bodyを中心とし た結節状の肥厚および弁尖の rolling が著明であり, coaptation が著しく不足し, 中心からの逆流の原因と 思われた. 弁尖・弁輪の大きさは均等ではなく, 左・ 右冠尖と比較し無冠尖は小さかった。機械弁 On-X ${ }^{\circledR}$ $19 \mathrm{~mm}$ (CryoLife, Inc. Kennesaw, GA, USA) での大 動脈弁置換術を施行した。大動脈壁の厚さは極端に薄

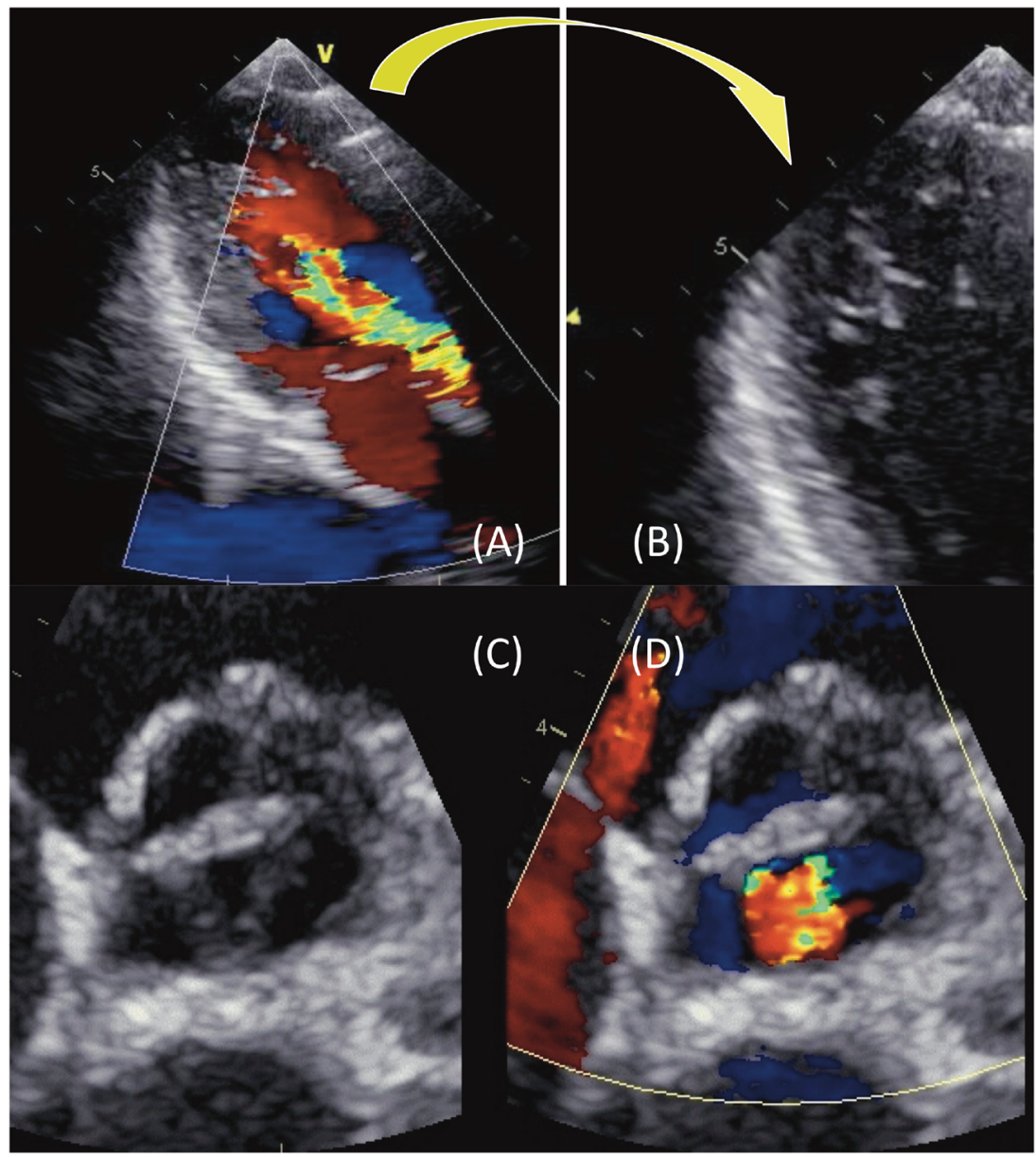

Fig. 2 Ultrasound echocardiography

(A) The moderate to severe aortic regurgitation was shown in the long-axis view. (B) The left ventricular noncompaction was suspected on the apex. (C) All the three cusps were thickened and retracted, and the coaptation was insufficient. (D) The regurgitant flow emerged through the central triangle gap. 
くはなかったが, 大動脈壁切開時に抵抗が小さく, 牽引時にも容易に損傷され, 組織の脆弱性が示唆され た. 大動脈壁へのストレス軽減の目的に, 大動脈切開 部は人工血管のパッチを補填して閉鎖した. 人工心肺 からの離脱は容易であり, 術後経過も良好で, 術後 20 日目に退院となった. 当初は 18 番染色体部分トリ ソミー・部分モノソミーと思われていたが, 外来経 過中に行ったアレイ CGH+SNP 解析では, 18 番染 色体長腕にコピー数の変化 [arr[hg19］18q22.1qter （61618860_78012829）×1］を認め, 最終的には 18 番

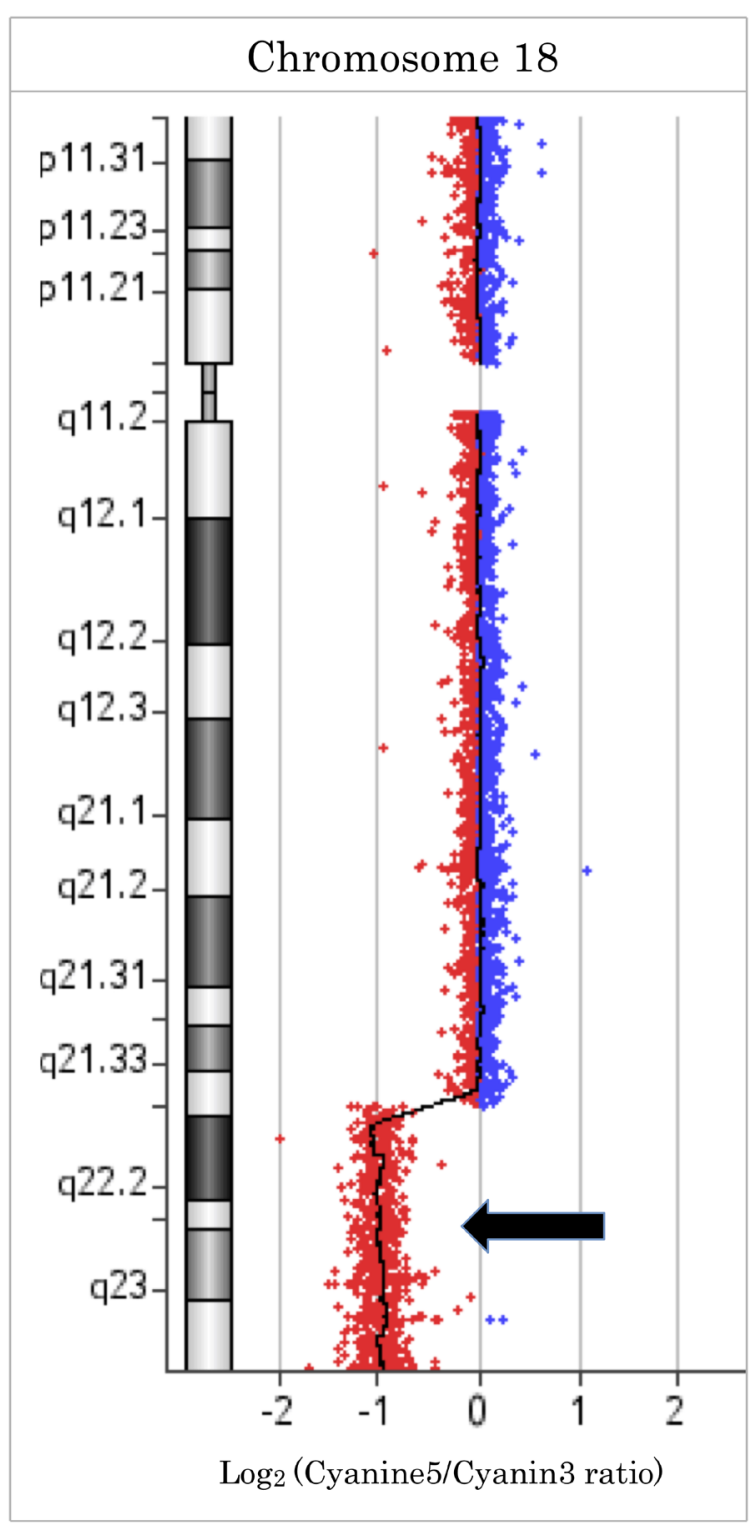

Fig. 3 Array CGH+SNP

The result of array $\mathrm{CGH}+\mathrm{SNP}$ in chromosome 18 showed the deletion from 18q22.1 to 18qter [arr[hg19] 18q22.1qter(61618860_78012829) $\times 1]$ (black arrow).
染色体部分モノソミーの診断となった（Fig. 3). 術後 1 年目頃より軽度の弁周囲逆流を認めているが, 増悪 を認めず良好に経過している。

\section{病理診断:}

\section{大動脈弁}

3 尖とも線維性に肥厚しており, 弁尖が結節状に変 化していた。 また, Alcian-blue 陽性の粘液状基質の 沈着が目立ち, 中等度の変性を伴う大動脈弁の組織像 であった (Fig. 4).

\section{大動脈壁}

中膜において弾性線維の伸延化や途絶・消失が部 分的に見られた. Alcian-blue 陽性の基質が目立ち, 中等度以上の変性を伴う大動脈壁の組織像であった (Fig. 5).

\section{考察}

18 番染色体部分モノソミー（18q-症候群）は, 1964 年に du Grouchy らが報告して以来, 多数の報 告がある ${ }^{1)}$. その発生頻度は $1 / 40,000$ とされ, 染色 体異常の中では比較的多く見られる疾患であり，男女 比は 2: 3 とやや女性に多い ${ }^{2)}$. 大多数は de novo 発症 （80\%）であるが，10\%は両親のいずれかの染色体異 常（転座や逆位など）に由来するとされ，遺伝カウ ンセリングの対象となる ${ }^{3)}$. 症例の多くは $18 \mathrm{q} 21.1$ と qterの間に breakpoint を持つが，約 10〜20\%は近位 部に breakpoint を持つという報告もある ${ }^{3)}$. 18q-症 候群の phenotype は多彩であり, 久失領域が大きい ほど症状が強い。 なかでも低身長，小頭症，特異的顔 貌，外耳道閉鎖，足変形，筋緊張低下などは比較的よ く見られ，これらの表現型と欠失部位遺伝子との関連 が次々と報告されている ${ }^{4)}$ (Table 1).

18q-症候群の予後については，おおむね良好である とされるが, $10 \%$ 前後が生後数か月以内に死亡すると いう報告もある ${ }^{5)}$. また Soileau らは，306 例の 18q症候群における生命予後を検討しており，18q-症候群 の中でも近位部 $18 \mathrm{q}-や \mathrm{TCF} 4{ }^{+/+}$の症例と比較して, complex rearrangement を持つ症例や $\mathrm{TCF} 4^{+/-}$は比較 的死亡率が高いと報告している ${ }^{6)}$.

18q-症候群における先天性心疾患の合併は，およそ 24〜35\%とされる ${ }^{7)}$. その内訳は, 肺動脈弁形態異常 が $47 \%$ と最も多く, 次いで心房中隔欠損症 26\%，心 室中隔欠損症 16\%, 大動脈弁狭窄症 16\%で，その他 肥大型心筋症, 総肺静脈還流異常症, Ebstein 奇形, WPW syndromeなども報告されており，多岐にわた $3^{8)}$. また, 本症例では左室心尖部に non compac- 

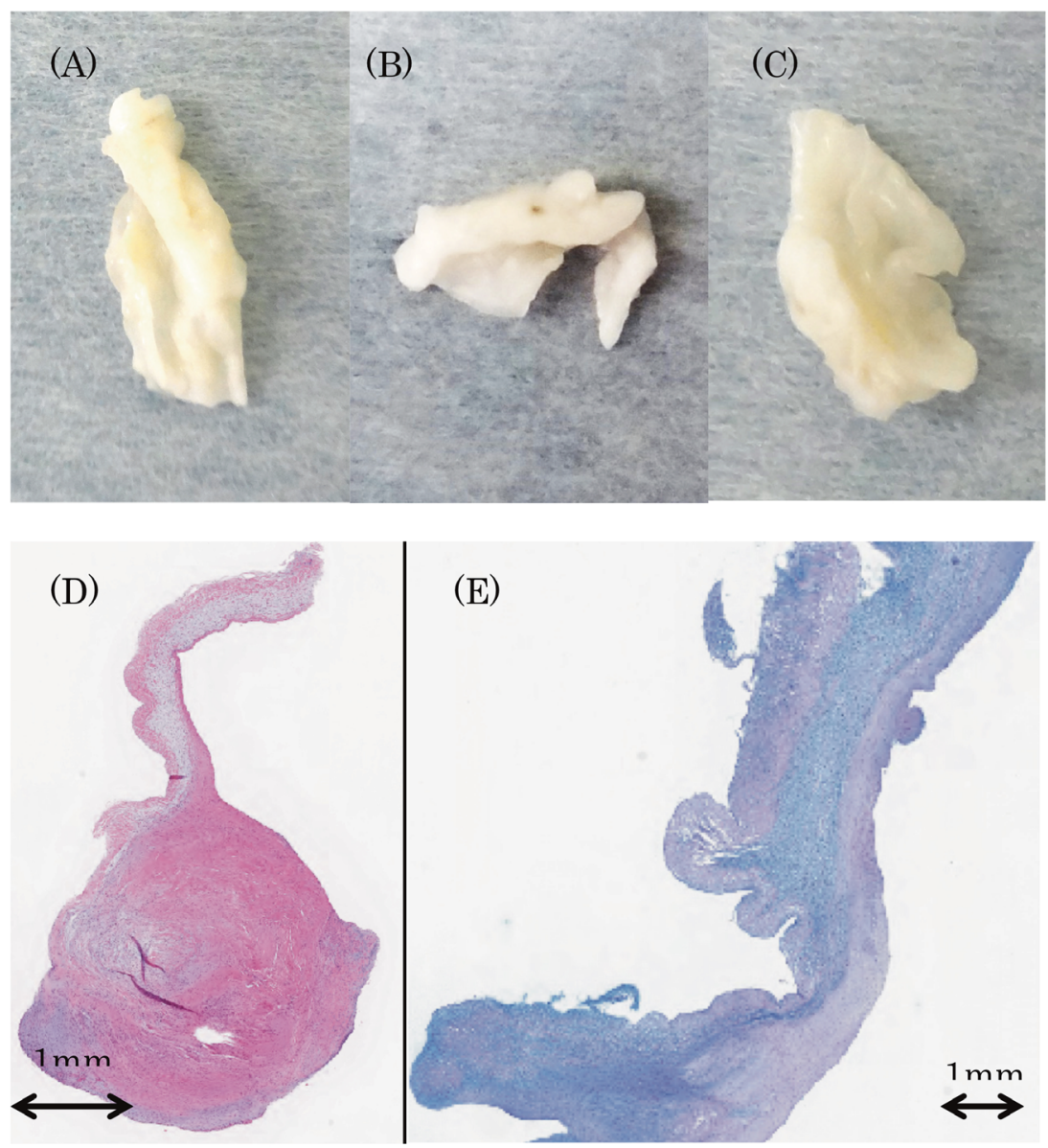

Fig. 4 Pathological examination (Aortic valve)

(A) Left-coronary cusp (B) Non-coronary cusp (C) Right-coronary cusp. Each leaflet thickened mainly around Arantius body. (D) Hematoxylin-Eosin stain on the aortic valve. Nodular thickening and hyalinization were confirmed. (E) AlcianBlue and PAS stain on the aortic valve. The myxomatous change was confirmed all around the aortic valve.

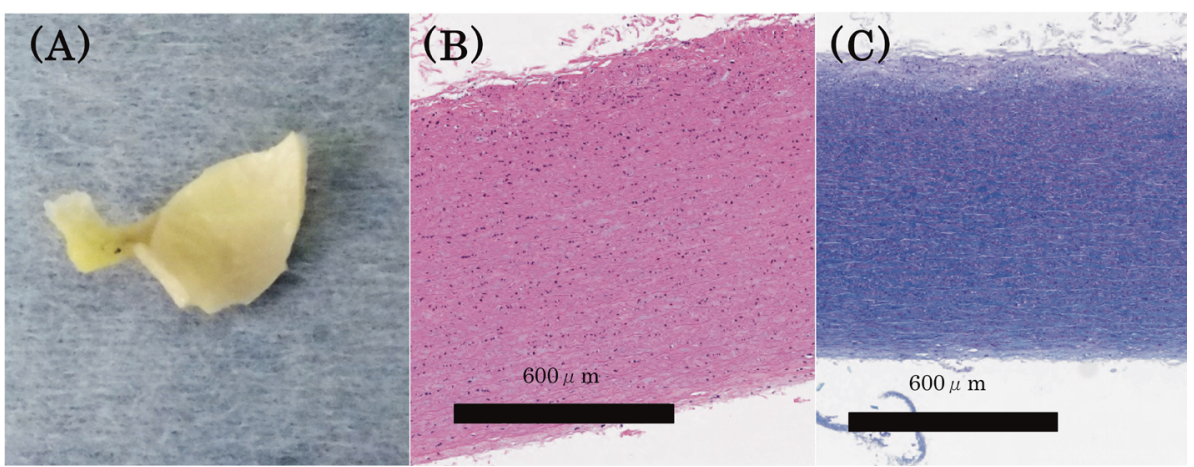

Fig. 5 Pathological examination (Aorta)

(A) The trimmed aortic wall during the closure of aortotomy. Macroscopically significant findings were not observed. (B) Hematoxylin-Eosin stain on the aortic wall. The lengthening, disruption, and effacement of the collagen fiber in aortic media were partially observed. (C) Alcian-Blue and PAS stain on the aortic wall. The myxomatous change was confirmed all around the aortic wall. 
Table 1 Summary of gene mutations in 18q-syndrome

\begin{tabular}{lll}
\hline \multicolumn{1}{c}{ Gene } & \multicolumn{1}{c}{ Location } & \multicolumn{1}{c}{ Phenotypes } \\
\hline GATA6 & $19,749,404-19,782,491$ & Complex congenital heart disease \\
ZNF521 & $22,641,888-22,932,214$ & Minor bone morphology changes \\
SS18 & $23,596,217-23,670,611$ & Growth failure \\
ZNF24 & $32,912,178-32,924,426$ & CNS dysmyelination \\
SETBP1 & $42,260,863-42,648,475$ & Expressive speech delay \\
SLC14A2 & $42,792,947-43,263,060$ & Vesicouretreral reflux/hydro- nephrosis \\
SMAD4 & $48,556,583-48,611,411$ & Polyposis \\
TCF4 & $52,889,562-53,303,188$ & Pitt- Hopkins syndrome \\
TXNL & $54,270,053-54,306,774$ & Intellectual disability \\
NETO1 & $70,409,549-70,534,810$ & Executive function impairment \\
CYB5A & $71,983,110-72,026,422$ & Male infertility/hypospadias \\
TSHZ1 & $72,997,498-73,000,596$ & Aural atresia \\
MBP & $74,690,789-74,844,774$ & High frequency sensorineural hearing loss \\
\hline
\end{tabular}

tion 様の変化を認めた。諸家の報告によると, $M Y H 7$ mutation と left ventricular non compactionの関連 を示唆するものがあるが ${ }^{9,10)}$, 本症例では MYH7 の mutation は検討しておらず，詳細は不明である.

手術適応に関して, 本症例は心疾患以外に生命的予 後を規定する表現型が存在しない点や, 心不全が進行 性に増悪している点, 両親の積極的なケアが期待でき る点を考慮して, 手術適応と判断した. 大動脈弁への 介入方法に関しては, 術前の心エコー検査で大動脈弁 の肥厚・短縮が著明であり, 術中所見でもそれらが確 かめられたので, 弁形成術は困難と判断した。 また, 患児は既に成人期に達しており, 今後の身体的成長を 考慮する必要性は低かったため, 代用弁による弁置換 術を選択した。 人工弁選択に扔いては, 本症例のよう に精神発達遅滞を有する染色体異常症例には, 様々な 点を考慮すべきである. 特にワルファリンによる抗 凝固療法の可否や家族の介入度, および疾患そのもの の予後を総合的に判断して人工弁選択を行う必要があ る. 本症例では, 現時点で心疾患以外には生命的予後 を規定する因子はなく, 異種生体弁の耐用年数よりも 長期間生存する確率が高いと予想され, その点をご家 族にお話しし，ご家族が機械弁を希望され機械弁の選 択となった.

術中に採取された大動脈弁尖の病理組織所見では, 比較的高度な厶コ多糖類の沈着が認められた。成人の 大動脈弁閉鎖不全症の弁尖にムコ多糖類の沈着を認め ることは稀ではないが, 19 歳の本症例に高度に認め られたことは, 先天的な器質的異常からもたらされ たものと考えられる. 同様に, 大動脈壁においても, ムコ多糖類の沈着とともに中膜の弾性線維の伸延化や 途絶・消失が認められた。これらは Marfan 症候群の 大動脈壁の病理組織学的所見と類似するものである.
Versacci らは肺動脈欠損を伴う 18q-症候群の症例報 告の中で, Marfan 症候群に類似した心臓大血管異常 や心外奇形を呈する事があると報告している7)．18q症候群における大動脈弁および大動脈壁の詳細な病理 学的検討の報告はないため, 本症例の大動脈壁の変性 が先天的な脆弱性によるものなのかは不明であるが, Marfan 症候群患者が心蔵大血管の臨床的特徵を表し 始める年齢と同等である点が興味深い ${ }^{11)}$. 本症例で は術直後には認められなかった人工弁周囲逆流が術後 1 年頃より出現しており, この点も Marfan 症候群に 認められる組織脆弱性を共有するものである．長期に わたる慎重な経過観察が必要であると考える.

\section{結 語}

18q-症候群に対する機械弁を用いた大動脈弁置換 術の一例を報告した. 18q-症候群における大動脈弁 疾患の手術症例報告はなく, 病理組織学的検査では Marfan 症候群に特徵的な大動脈弁・大血管異常と同 様の所見が認められた。この疾患群の詳細な経過を記 録しそれらを蓄積していくことで, 病態の理解が深ま るものと思われる。

\section{利益相反}

本論文について開示すべき利益相反（COI）はない.

\section{引用文献}

1) De Grouchy J, Royer P, Salmon C, et al: Partial deletion of the long arms of the chromosome 18. Pathol Biol (Paris) 1964; 12: 579-582

2）倉橋 浩：【小児の症候群】染色体異常・先天奇形症候 群 18p モノソミー. 小児科診療 2009; 72: 17 
3) Feenstra I, Vissers LE, Orsel M, et al: Genotype-phenotype mapping of chromosome 18q deletions by high-resolution array CGH: An update of the phenotypic map. Am J Med Genet A 2007; 143A: 1858-1867

4) Cody JD, Sebold C, Heard P, et al: Consequences of chromsome18q deletions. Am J Med Genet C Semin Med Genet 2015; 169: 265-280

5) Miller G, Mowrey PN, Hopper KD, et al: Neurologic manifestations in 18q- syndrome. Am J Med Genet 1990; 37: $128-132$

6) Soileau B, Hasi M, Sebold C, et al: Adults with chromosome 18 abnormalities. J Genet Couns 2015; 24: 663-674

7) Versacci P, Digilio MC, Sauer U, et al: Absent pulmonary valve with intact ventricular septum and patent ductus arteriosus: A specific cardiac phenotype associated with deletion 18q syndrome. Am J Med Genet 2005; 138A:
$185-186$

8) van Trier DC, Feenstra I, Bot P, et al: Cardiac anomalies in individuals with the 18q deletion syndrome: Report of a child with Ebstein anomaly and review of the literature. Eur J Med Genet 2013; 56: 426-431

9) Postma AV, van Engelen K, van de Meerakker J, et al: Mutations in the sarcomere gene MYH7 in Ebstein anomaly. Circ Cardiovasc Genet 2011; 4: 43-50

10) Budde BS, Binner P, Waldmuller S, et al: Noncompaction of the ventricular myocardium is associated with a de novo mutation in the beta-myosin heavy chain gene. PLoS One 2007; 2: e1362

11) Groth KA, Hove $\mathrm{H}$, Kyhl K, et al: Prevalence, incidence, and age at diagnosis in Marfan Syndrome. Orphanet J Rare Dis 2015; 10: 153 